mination of his legs, a very large ulcer was seen on one calf, and a little nlcerated point, communicating with a small but deep cavity, on the other. The linger one, he informed me, bad commenced in a little spot about a fortnight previously, and had for some days been spreading very rapidly, causing much severe pain and constitutional irritation. It now presents the peculiar appearance of a slonghing mercurio-syphilitic ulcer, exactly circular, about two inclies in depth, considerably excavated; the whole circumference, for the distance of an inch and a half or two inches from the edges, is hard, red, and extremely sensitive; there is a discharge of dirty-looking sloughy matter and acrid sanious fluid. In spite of the vigorous and judicions measures advised by an eminent London surgeon, who had been consulted a few days previously, the sloughing ulceration is rapidly extending; and in the excessively prostrated condition of the sufferer the case appears by no means hopeful.

Here an opportunity offered of severely testing the power of oxygen; and knowing what this therapeutic agent could effect in analogous non-syphilitic ulcers, and in most cases of extreme debility and langnid circulation, I at once determined energetically to bring it into action. My patient was ordered to preserve the horizontal position, and to foment, poultice, \&c. The same afternoon I administered a large dose of the gas, which had the effect of making him feel more comfortable. The following morning, the ulcer still alarmingly progressing, I carefully superintencled the administration of the largest quantity that could be borne, and ordered a moderate inhalation in the evening. From that time it spread no further, and by daily watching my patient during the succeeding fortnight I had the satisfaction to witness the separation of the dead portions, the perfect cleansing of the whole surface, (tho muscle being left exposed for snme distance, and its movements being seen at the bottom of the cavity.) and the gradual filling up of the depth with granulations; while at the same time the appetite returned, and the capillary circulation, with the entire nervous system, began to regain tone. Small doses of iodicle of potassium were now ordered three times a day, and nutritious but moderate diet with porter; cod-liver oil was rubbed in to the chest twice a day, and tepid daily sponging of the whole body was enjoined. In five weeks he was able to walk about, and in seven weeks entire healing of the large and deep excavation resulting from the ulceration had taken place, permitting him with his increase in strength to walk without difficulty many miles. He now left town, taking with him a supply of condensed oxygen, with a strict direction to continue his moderate inhalations, the iodide of potassium, and the codliver oil externally, and to communicate with me by letter once a week. Three weeks afterwards, having walked rather too much, and having otherwise irritated and injured the place on the otll\% leg, where the small point of ulceration had apparently healest muler the infuence of the oxygen without slough ing, he thought it advisalble to return to London. I found an ulcer of moderate size, much infiamed from irritation, rubbing of his trousers against it, and neglect; moreover he had caught a severe coll, and his congh (which had never left him), with profuse perspirations at night, caused much disturbance. He was feeble and extrenely sensitive to cold, although the weather was warm. I gave him stringent directions as to quiet for his leg, largely increased his quantity of oxygen at each inhalation night and morning, continned his other constitutional treatment as above mentioned for the specific diseases, and watched him closely by means of two long daily visits. He again progressed most satisfactorily, and was soon enjoying his favourite pedestrian exercise.

Steadily continning his treatment, he towards the middle of September had entirely lost his consumptive cough and nocturnal perspirations, had fully regained his nervous tone, and had recovered his flesh; he suffered no longer from cold and languid circulation; the dirty congested appearance beneath the cuticle had quite disappeared; the jaw (from which there had been some exfoliation) seemed quite sound, and the general cerebral irritation with iritis had for some weeks ceased to evidence itself, the effuscd lymph likewise having undergone complete absorption, and the membranes and chambers of the eye being quite clear and free in their movements.

About the end of October, this gentleman-an ardent disciple of Nimrod-wrote for permission to follow the hounds again. With a caution, I acceded to his request; and I have since learnt that he rode very hard during the hunting season without any return whatever of his former protracted disease. A few days ago, I may add, I heard some further account of him, and he is now stouter and stronger, and altogether in more robust health, than (he thinks) he ever recollects.
It is especially worthy of remark, with this interesting case in retrospect, that there exists probably no remedy at all comparable with oxygen as (in common parlance) a "purifier of the blood," when judlicionsly administered. My own experience particularly points to its well-marked and energetic action upon the general capillary circulation and upon the skin ; in most cases, it powerfully promotes the healthy secretions of the latter, and enables it to throw off an immense amount of morbid and poisonous matters; and, unlike all other medicines, while performing this duty, it produces no weakening or other untoward effect, but, on the contrary, simultaneously acts as a general tonic to the entire constitution. It will be observed that I ordered, as an esscntial adjunct to treatment, tepid sponging of the whole body daily, the poisonous détris cast off with the aid of the gas, and accumulating on the skin, obviously necessitating either such sponging or the use of the tepid bath. It also merits a passing notice how quickly the heroic doses of the gas, temporarily and carefully given, demonstrated the power of this therapeutic in cutting short and arresting the progress of rapidly-spreading ulceration.

I will give a second case very briefly, from memory, so as not to lengthen my present paper too mnch.

A. B_, a policeman, aged thirty-six, had been nearly three months under skilful medical treatment on account of inveterate boils and carbuncles, which, appearing in continuously successive crops, resisted every remedy. At length he was advised that medicine could do no more for him, and that he must get immediately into the country, for the purpose of trying what that change could effect. He was at this time covered with from twenty to thirty specimens of this very painful ermptive disease, and his health was necessarily much undermined from acute suffering and constitutional irritation. Being accirlentally met with, he was offered gratnitous treatment under oxygen. Having a family to provide for, he could ill affurd to leave them, and therefore thankfully accepted the proffer. He at once commenced a daily inhalation, and so rapid was his procress that in from ten days to a fortnight all the eruptions had entirely disappeared, and the unhealthy constitutional condition was so completely overcome as to render the cure permanent.

Regent-street, July, 1857.

\section{ON A CASE OF LUPUS EXEDENS.}

By R. BARWELL, EsQ., F.P.C.S., ASSISTANT-SURGEON TO THE CHARING-CROSS HOSPITAL.

From many observations that I have been able to make upon. indolent ulcers, more particularly upon lupus, I am led to the belief that the application of violent causties, as usually practised, is more injurious than otherwise. The tissues surrounding the ulcer are passively congested, and are also more or less infiltrated with an aplastic or cacoplastic material. Whem to such structure a strong caustic (nitric acid for instance) is applied, the parts in immediate contact with the escharotic are of course killed; those surrounding the eschar are influenced less violently, and are benefited for a time by the astringent power of the drug, which diminishes the congestion and the spongy condition. In a lew days, however, the action necessary to throw off the slough restores the congestion; effusion and donghy thickening follow as a matter of course, and the result is the extension of the disease upon a larger base.

From this groundwork of observation I was led to believe that the proper local remedy was a pure astringent void of all irritant action, and I made many cautious experiments upon ordinary indolent ulcers, with a view of ascertaining the best form of application. It appeared that mineral and earthy substances, if used sufficiently concentrated to produce a decidedly astringent effect, were also irritant; such at least was the case with the ordinary sulphates, nitrates, and acetates. Vegetable astringents, pyrethrum, kino, catechu, and many more, were then tried, with such results as induced me to make use of them in the following case:-

S. $\mathrm{N}$ - came to me on the 15 th of December, 1856. She is fourteen years old, small for her age, slim, of dark sallow complexion, and has on the upper lip a budding of hair, rather profuse for so young a girl. The circulation is languid, and she suffers much from cold feet. Catamenia have not yet appeared. The nose and right cheek are the seat of a foul, unhealthy ulceration, surrounded by spongy tissue of a dusky red 
colour. The whole nose is thicizened and enlarged by a tough inelastic deposit. The relness nearly reaches the cheek on the left, and on the right sicle extends some clistance on the face; the whole surface is studded with angry pimples and blotches. The sore itself covers the right ala nasi, has eaten through it in one part, and extends upon the top of the nose and upon the right cheek.

She states that in February, 1854,-that is, mearly three years previous to my seeing her, the disease appeared on the right side of the nose as a number of small pimples; these increased in size and number, and in about eight months broke out into an open sore. She has since that time unclergone a great deal of treatment: the sore has been burnt with nitric acid, with potassa fusa, and nitrate of silver, of which applications she has great dread, and under which she did not in prove.

A purified preparation of catechu, made by dissolving several times, pouring off the clear liquor, and evaporating to the consistence of treacle, was spread upon linen, aud applied over the reddened skin and ulcer; this was continued daily. The redness diminished to a considerable degree, and the pimples seemed less angry. In three weeks, however, the discharge began to increase again, and the application was changed to a strong decoction of oak bark. This preparation also answered for a month extremely well; the size and congestion of the parts continuing to diminish.

On the 10th of February tannic acid was used: it was dissolved in as small a quantity as possible of water, and applied with a camel's-hair brush. Each application almost instantly reduced the redness of the skin, and dried into a scab, which on the following day was removed, and a reapplication made. This treatment went on for some time, the sore decreasing in size. Occasionally a little disturbance in health would throw her back for a time; but still the improvement was tolerably uninterrupted.

On the 15th of May I began to diminish the strength of the tannic acid to so thin a solution that it did not form a seab, and this $I$ let her apply night and morning.

On the 22nd of June the solution used was only of the strength of twenty grains to the ounce, and on the $6 \mathrm{th}$ of July the sore was healed and the redness had nearly disappeared. It is probable that, in a short time, only the scar of the old ulceration will be left.

Burlington-street, July, 1857.

\section{RECOVERY AFTER SWALLOWING A LARGE QUANTITY OF ARSENIC.}

\section{BY THOMAS GODFREY, EsQ., M.R.C.S. \& L.S.A.,} Mansfield.

A MDDDLE-AGED woman, in perfect health, and of violent and impetuons temper, swallowed, in a paroxysm of rage and jealousy, a quantity of arsenic, equal in bulk to about a dessertspoonful. This she mixed in half a cupful of water, and swallowed it, having partaken freely, a few minutes before, of an abundant dinner of meat and suet pudding. Her violent excitement having soon after subsided, she confessed the fact, having previously informed her sisters, who witnessed the aet, that she had taken magnesia. I arrived in about one hour and a half from the time of her swallowing the dose; and being unaware of the nature of the occurrence, could only exhibit an emetic of sulphate of zinc, which I happened to have with me. This produced frequent romiting, which was promoted by repeated draughts of warm water. Having obtained hydrated peroxide of iron from my surgery, for which I had to send one mile and a half, $I$ administered it freely, suspended in treacle and water, so that in three hours from the time of swallowing the arsenic, she had drank abont four pints of water, and from seven to eight ounces of the peroxide, no portion of which was retained beyond five minutes. At one time the prostration became alarming, the pulse bein $:$ rapid, and barely appreciable, the features distorted, cold perspiration of the body, and severe rigor.

In five honrs from taking the arsenic, she resolutely refused to swallow more liquid; and as she lad rallied considerably, and appeared drowsy, she was permitted to sleep for seven hours. when she appeared quite recovered, and free from any 114 suspicious symptom beyond a slight epigastric tenderness, which I referred to the frequent vomiting, but for which, as a precautionary measure, I prescribed calomel and opium. In twenty-four hours from this time, I discontinued the pills; nor was there any indication for further treatment, her convalescence fullowing so rapidly that in five days she had resumed her domestic duties.

Notts, July, 1857.

\section{a 3 Atruror}

OF THE PRACTICE OF

\section{MEDICINE AND SURGERY IN THE}

\section{HOSPITALS OF LONDON.}

Nulla est alia pro certo noscendi vich, nisi quam plurimas et morborum e dissectionum historias, tam aliornm proprias, collectas habere et inter se com parare.-Morgagnr. De Sed. et Cauls. Morb. lib. 14. Prowmium.

\section{GUY'S HOSPITAL.}

ALC THE VIARIETIES OF TUMOUR BELONGING TO THE CLASS ADENOCELE DEVELOPED WITHIN A SINGLE PREAST; SUCCFSSFUL EXTIRPATION; THE GLAND ASSUNTNG ITS NORMAL OUTLINE.

\section{(Under the care of Mr. Birizetr.)}

ONE of the most remarkable, interesting, and instructive examples of the development of all the known forms of inno. cent tumours affecting the mammary gland within a single breast we saw at this hospital some weeks back. The new growth was what Mr. Birlett described as an epitome of every variety of tumour which belongs to the great class adenocele, an account of which disease he has fully given in the first volume of the third series of "Guy's Hospital Reports."

In the tumour which was remored from the breast, under the influence of chloroform, we saw in the centre the chronic mammary tumour of Sir Astley Cooper, the pancreatic sarcoma of Abernethy, the sero-cystic disease of Brodie, the carcinoma mammæ hydatidis of Sir Chas. Bell, one of the forms of hydatid disease of the breast of Sir A. Cooper; in fact, every form of innocent growth in the breast described by such names.

The varieties of adenocele in the mammary gland are exhibited under three very different forms and aspects, and we have established, Mr. Birkett thinks by Nature, three very marked divisions of these growths. These are of such interest in connexion with the case which we report to day, that we offer no apology for giving them:-

"The first division consists of new growths, which are compact, dense, firm, fibrous, lobed on their surface and in their interior, and enveloped in their own fibrous capsule. The second, of cystoid formations, having growths within them, which appear to spring from their walls; these growths being loose, pedunculated, and floating or sessile, and with no connective lissue between them, its place being often supplied by fluid. And the third, of cystoid formations, distinctly referable to the dilatation of a duct, or to a connexion with one, and containing growths which appear to spring from their walls." -p. 138.

Mr. Birkett has included in the first division those tumours termed by Sir A. Cooper, "chronic mammary tumour;" by Cruveilhier, "corps tibrenx;" by Lebert, "bypertrophie partielle ;" by Velpean, " tmmour adenoide ;" by Paget, "mammary glandular tumour." In the second, the tumour described by Sir A. Cooper, "hydatid disease of the breast;" by Müller, as "cysto-sarcoma" by Sir Charles Bell, "carcinoma mamma hydatidis;" by Sir Benjamin Brodie, "serocystic tumours;" by Paget, "proliferous cysts." In the third, the variety described by Sir B. Brodie, in his Lectures illustrative of various subjects in Pathology and Surgery, as arising "by a dilatation of portions of some of the lactiferous tubes,"

We cannot venture into a consideration of all these; but it has been shown by Mr. Birkett that they preponderate in single women. He has given as many as 45 in 62 cases; and 